\title{
Rancangan Service Scorecard sebagai Pengukuran Kinerja Pelayanan Cargo
}

\author{
Nurlailah Badariah ${ }^{1)}$,Tiena Gustina Amran $^{2)}$, dan Aditya Friandy ${ }^{3)}$ \\ ${ }^{102) 3)}$ Jurusan Teknik Industri, Fakultas Teknologi Industri, Universitas Trisakti \\ Penulis untuk Korespondensi/E-mail: nurlailah_ms@yahoo.co.id, tiena_amran@yahoo.com, \\ randi_friandi@yahoo.com
}

\begin{abstract}
Abstrak - Persaingan antara pelaku bisnis charter flight semakin ketat dalam persaingan global. perusahaan harus dinamis dan adaptif terhadap perubahan lingkungan bisnis. Perubahan ke arah strategi yang dapat diimplementasikan sesuai dengan perkembangan persaingan charter flight untuk pelayanan yang terbaik bagi pelanggan. Penelitian ini menggunakan pendekatan aplikatif yaitu merancang suatu sistem yang dapat diaplikasikan pada perusahaan charter flight, yang telah memiliki sistem pengelolaan kinerja dengan menggunakan Balanced Scorecard. Pada perancangan Balanced Scorecard terdapat 4 perspektif utama yaitu : financial perspective, customer perspective, internal business processes, learning and growth perspective. Balanced Scorecard tidak di desain secara spesifik untuk perusahaan jasa dan tidak bersifat prediksi. Sementara Service Scorecard memfokuskan spesifik pelayanan pada customer perspective. Dari hasil penelitian diperoleh Strategy Mapping yang memuat tujuan-tujuan strategis dan indikator (Lead dan Lag) dari Service Scorecard. Terdapat 17 ukuran kinerja yang temuat di dalam 17 tujuan strategis dan 7 perspektif dari Service Scorecard yaitu : Growth, Leadearship, Acceleration, Collaboration, Innovation, Execution, Retention. Tujuan strategis yang dibuat dalam suatu Strategy Mapping dan indikator sangat berguna untuk menyusun langkah selanjutnya yang akan ditempuh oleh perusahaan.
\end{abstract}

Abstract - Competition between charter flight businesses increasingly stringent in a global competition. Companies must be dynamic and adaptive to changes in the business environment. Changes in the direction of strategy that can be implemented in accordance with the competition development of charter flight for the best service for customers. This research uses applicative approach to design a system that can be applied to the charter flight company, which already has a performance management system by using the Balanced Scorecard. In the Balanced Scorecard, there are four main perspectives: financial perspective, customer perspective, internal business processes, learning and growth perspective. Balanced Scorecard is not designed specifically to service companies and non-predictive. While the Service Scorecard specific focus on customer service perspective. This research has resulted a strategy map with subsequent strategic objectives and indicator (Lead and Lag) for Service Scorecard. Finally, there are 17 performance measures with subsequent 17 strategic objectives and 7 perspectives Service Scorecard: Growth, Leadearship, Acceleration, Collaboration, Innovation, Execution, Retention. Strategic goals made in a Mapping Strategy and indicator is very useful to formulate the next steps to be taken by the company.

Keyword - Service Scorecard, Balanced Scorecard, Strategy Mapping, customer perspective, Lead dan Lag

\section{PENDAHULUAN}

$\mathrm{B}$ isnis penerbangan, merupakan salah satu jenis bisnis yang sangat menjanjikan saat ini. Perkembangan bisnis ini terlihat dengan banyaknya perusahan penyedia layanan jasa penerbangan. Faktor inilah yang memacu setiap perusahaan penerbangan untuk dapat survive dan terus tumbuh dalam memperluas pasarnya. Perluasan pasar secara langsung ditandai dengan meningkatnya penjualan jasa, dengan sendirinya akan meningkatkan jumlah pelanggan. Namun, ada beberapa hal yang harus dipahami oleh perusahaan selaku pihak penyedia jasa, bahwa 
semakin banyak pelanggan maka perusahaan akan semakin sulit mengenali pelanggannya secara rinci terutama tentang suka atau tidaknya pelanggan terhadap jasa yang ditawarkan dan alasan yang mendasarinya.

Loyalitas pelanggan ditentukan oleh proses pelayanan yang dilakukan perusahaan penerbangan yang meliputi pre flight, in flight dan post fight. Kualitas pelayanan digambarkan sebagai suatu pernyataan tentang sikap, hubungan yang dihasilkan dari perbandingan antara ekspektasi dengan kinerja. Dengan demikian kualitas pelayanan dapat didefinisikan seberapa jauh perbedaan antara kenyataan dan harapan para pelanggan atas layanan yang mereka terima. Loyalitas pelanggan terhadap kualitas jasa tersebut dapat diukur dari terpenuhi atau tidaknya kebutuhan pelanggan yang tampak dari sikap perilaku pelanggan terhadap suatu produk atau jasa. Dengan adanya kualitas pelayanan yang baik di dalam suatu perusahaan, akan menciptakan kepuasan bagi pelanggannya.

Ada beberapa hal yang membuat pengukuran kinerja itu begitu penting. Diantaranya menurut Linch dan Cross yang dikutip oleh Kaitosh menyatakan manfaat sistem pengukuran kinerja yang baik diantaranya adalah: a) menelusuri kinerja terhadap harapan pelanggan sehingga akan membawa perusahaan lebih dekat pada pelanggannya dan membuat seluruh orang dalam organisasi terlibat dalam upaya memberi kepuasan kepada pelanggan. b) memotivasi para pegawai untuk melakukan pelayanan sebagai bagian dari mata rantai pelanggan dan pemasok internal.c)membangun komitmen untuk melakukan suatu perubahan dengan melakukan evaluasi atas perilaku yang diharapkan tersebut [1]. Untuk mencapai manfaat dari pengukuran kinerja tersebut, maka paling tidak harus memiliki syaratsyarat sebagai berikut: a) didasarkan pada masingmasing aktivitas dan karakteristik organisasi itu sendiri sesuai perspektif pelanggan. b) Evaluasi atas berbagai aktivitas. c) dapat dinilai dengan menyeluruh, yaitu semua aktivitas dalam organisasi tersebut, dan d) membantu seluruh organisasi mengenali masalah yang ada dengan kemungkinan melakukan perbaikan. Ada beberapa hal yang dapat diukur oleh perusahaan di dalam perspektif pelanggan ini, diantaranya Market Share: pengukuran ini mencerminkan bagian yang dikuasai perusahaan atas keseluruhan pasar yang ada, yang meliputi jumlah pelanggan, jumlah penjualan dan volume unit penjualan.

Dalam penelitian ini akan dirancang sebuah strategi map yang memuat tujuan-tujuan strategis dan indikator (Lead dan Lag) dari PT. Pelita Air Service (PAS) yang terbagi dalam 7 perspektif Service Scorecard, yaitu Growth, Leadearship, Acceleration, Collaboration, Innovation, Execution, Retention. Menurut Rajesh K.Tyagi dalam pembuatan Service Scorecard dipengaruhi oleh tujuan strategis yang diketahui pada balanced scorecard yang menetapkan strategi perusahaan dan tujuan strategis yang terlihat pada peta strategi Balanced Scorecard berdasarkan 4 perspektif, yaitu financial perspective, customer perspective, internal business processes, learning and growth perspective [2]. Berdasarkan manfaat pengukuran kinerja di atas yang menitikberatkan pada harapan pelanggan maka Service scorecard memfokuskan spesifik pelayanan pada customer perspective dengan kemampuan perusahan dalam menjalankan tujuan strategis tersebut.

\section{TINJAUAN PUSTAKA}

Pengukuran sistem kinerja, khusus untuk sistem jasa pelayanan sangatlah unik dan berbeda dari pengkuran kinerja barang real. Banyak faktor baik eksternal maupun internal yang mempengaruhi baik buruknya kinerja suatu perusahaan dalam bidang jasa. Ada beberapa tantangan dalam membuat atau mengukur suatu kinerja dalam sistem pelayanan jasa. Customer-Introduced Variability yaitu variansi permintaan pelanggan yang menciptakan suatu variabilitas yang berbeda. Frances X.Frei, dalam artikelnya Harvard Business Review, menyarankan bagaimana untuk mengatur keterlibatan pelanggan dalam operasi pelayanan untuk memberikan kualitas yang konsisten dengan biaya yang secukupnya. Dalam dunia produk, perusahaan menghadapi variabilitas yang berbeda hanya dari proses produksinya saja. Dalam pengaturan pelayanan, faktor pelanggan memberikan tambahan variabilitas yang berbeda, karena mereka merupakan bagian dari proses produksi tersebut. Service Inventory and Service Delivery System yaitu bagaimana suatu perusahaan menciptakan suatu pelayanan dan sistem pelayanan terhadap pelanggan. Jenis permintaan pelanggan bisa di penuhi dengan sistem pelayanan jasa, make-to-stock dan make-to-order. Seperti 
contoh pelayanan make-to-stock yaitu pelayanan jasa yang berkeliling kota untuk mencari pelanggan. Sedangkan contoh make-to-order yaitu pelayanan jasa penerbangan, dimana rute penerbanganpunakan dibuka apabila ada permintaan dari pelanggan. Seberapa baiknya atribut sistem pelayanan kepada pelanggan, sangat berpengaruh terhadap perusahaan tersebut.

Untuk merancang sistem pengukuran kinerja, terlebih dahulu harus dimengerti karakteristik dari pelayanan, berbagai subkonteks bisnis dalam domain pelayanan dan keunikan yang disajikan dalam konteks ini. Karakteristik tersebut meliputi, intangibility jasa, produksi simultan dan konsumsi, dan kedekatan dengan pelanggan, benar-benar dibahas dalam literatur tersebut.

Mengenali keunikan dari operasi sistem pelayanan jasa, Parasuraman, Zeithaml, dan Berry mengindentifikasi 5 dimensi dari kualitas service (service quality) sebagai elemen penunjang kerangka yang biasa disebut dengan ServQual. Kelima dimensi tersebut adalah nyata/berwujud, berkeandalan, responsif, kredibilitas, dan empat dimensi-dimensi tersebut telah memperoleh pengaruh yang sangat signifikan dalam mengevaluasi beberapa jenis pelayanan jasa, termasuk kesehatan, perbankan, dan sektor pendidikan.

Secara operasionalnya, pelayanan jasa mempunyai komponen transaksi dan interaksi. Interaksi dibutuhkan untuk mendapatkan informasi pelanggan atau permintaan pelanggan, sehingga pemenuhan permintaan dapat dilakukan. Aspek transaksi dari pelayanan jasa harus lebih banyak dilakukan saat memproduksi suatu jasa, seperti dibidang keuangan/financial atau industri makanan. Tipikal dari operasi pelayanan jasa melibatkan lebih banyak interaksi daripada transaksi. Aspek transaksi lebih cenderung membutuhkan ketergantungan teknologi, dan aspek interaksi lebih cenderung membutuhkan ketergantungan terhadap manusia.

Balanced scorecard merupakan konsep manajemen yang diperkenalkan Robert Kaplan tahun 1992, sebagai perkembangan dari konsep pengukuran kinerja (performance measurement) yang mengukur perusahaan [3]. Robert Kaplan mempertajam konsep pengukuran kinerja dengan menentukan suatu pendekatan efektif yang seimbang (balanced) dalam mengukur kinerja strategi perusahan. Pendekatan tersebut berdasarkan 4 perspektif yaitu financial perspective, customer perspective, internal business processes, learning and growth perspective. Keempat perspektif ini menawarkan suatu keseimbangan antara tujuan jangka pendek dan jangka panjang dari hasil yang diinginkan (Outcome) dan pemicu kinerja (performance drivers) dari hasil tersebut dan tolok ukur yang keras dan lunak serta subjektif.

Pada awalnya Balanced scorecard diciptakan untuk mengatasi problem tentang kelemahan sistem pengukuran kinerja eksekutif yang berfokus pada aspek keuangan. Selanjutnya Balanced Scorecardmengalami perkembangan dalam implementasinya, tidak hanya sebagai alat pengukur kinerja eksekutif, namun meluas sebagai pendekatan dalam penyusunan rencana strategis, Balanced Scorecard mengembangkan seperangkat tujuan unit bisnis melampaui rangkuman ukuran finansial. Para eksekutif perusahaan sekarang dapat mengukur seberapa besar berbagai unit bisnis mereka menciptakan nilai bagi para pelanggan perusahaan saat ini dan yang akan datang, dan seberapa banyak perusahaan harus meningkatkan kapabilitas internal dan investasi di dalam sumber daya manusia, sistem dan prosedur yang dibutuhkan untuk meningkatkan kinerja yang akan datang Balanced Scorecard mencakup berbagai aktivitas penciptaan nilai yang dihasilkan oleh para partisipan perusahann yang memiliki kemampuan dan motivasi tinggi, sementara tetap memperhatikan kinerja jangka pendek yaitu melalui perspektif finansial.

Service Scorecard terdiri dari dua kata, yaitu "Scorecard" yang artinya kartu skor dan "service" yang artinya pelayanan. Kartu skor adalah kartu yang digunakan untuk mencatat hasil kinerja pelayanan dan merencanakan skor yang ingin dicapai di masa mendatang, sehingga dalam kartu skor juga terdapat perbandingan antara hasil kinerja sesungguhnya dengan target yang hendak dicapai

Tujuh elemen pada Service Scorecard Architecture menurut Gupta, meliputi: Growth, Leadership, Acceleration, Collaboration, Innovation, Execution, dan Retention [4]. Tujuh elemen ini dimasukkan bersama dalam suatu model (GLACIER) yang mempresentasikan atribut berwujud tertentu dalam bisnis pelayanan jasa.Sama dengan GLACIER, bisnis pelayanan jasa juga secara berkelanjutan berubah-ubah sesuai dengan bata-batas yang didefinisikan oleh 
pelanggan, mengadaptasi dengan bermacammacam jenis pelanggan, mengenali dalam mengambil suatu bagian untuk suatu ekosistem bisnis.

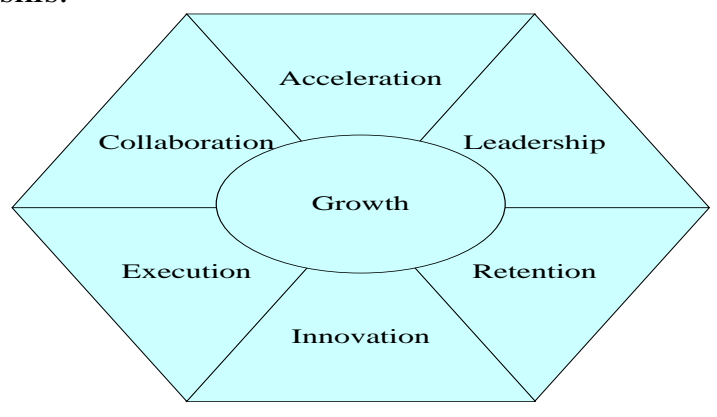

Gambar 1. Service Scorecard Architecture [2]

Ketika suatu organisasi mengimpelentasikan suatu Service Scorecard, dampaknya harus benar-benar dimengerti secara keseluruhan dalam hal pengembalian investasi, Service Scorecard harus menjadi indikator utama dalam kesuksesan suatu korporasi. Scorecard tersebut harus diadaptasi oleh organisasi jasa berdasarkan model bisnis mereka masing-masing dalam penggunaanya. Sebagai contoh, beberapa perusahan yang menyetir harga dengan fokus dalam penjualan dengan harga yang lebih rendah dari pesaingnya, contoh Wal-Mart, IKEA, Southwest, Motel 8, dan Shouldice Hospital. Ada juga organisasi yang berkembangan dengan mencari perbedaan atau ciri khas dari pelanggannya, seperti Disney, hard Rock Café, Dell, Ritz Carlton, dan Macy`s.

Pada perusahan-perusahaan tersebut, inovasi adalah suatu aspek kritis yang dapat mengembangkan bisnis mereka.Selain itu ada beberapa organisasi yang harus responsif terhadap kebutuhan pelanggan dimana kecepatan waktu lebih diutamakan daripada segi biaya.Perusahaan seperti FedEx, UPS, Restoran fast-food, rumahsakit, memiliki pelanggan dimana pelanggannya membutuhkan ketergantungan utama pada kecepatan pelayanan baru diiringi dengan kualitas dan biaya yang baik pula.

\section{METODOLOGI PENELITIAN}

\section{Perancangan Balance Scorecard}

Langkah-langkah yang dilakukan dalam perancangan Balance Scorecard meliputi analisa SWOT, Identifikasi Positioning dengan Matriks IFE dan EFE, Perancangan Matriks SWOT dan Peta Strategi Balance Scorecard. Balanced Scorecard dengan jelas mengungkapkan berbagai faktor yang menjadi pendorong tercapainya kinerja finansial dan kompetitif jangka panjang yang superior. Tujuan dan ukuran scorecard diturunkan dari visi dan strategi. Tujuan dan ukuran tersebut memandang kinerja perusahaan dari empat perspektif yaitu financial perspective, customer perspective, internal business processes, learning and growth perspective. Dalam Balanced Scorecard, keempat persektif tersebut menjadi satu kesatuan yang tidak dapat dipisahkan. Keempat perspektif tersebut juga merupakan indikator pengukuran kinerja yang saling melengkapi dan saling memiliki hubungan sebab akibat [3].

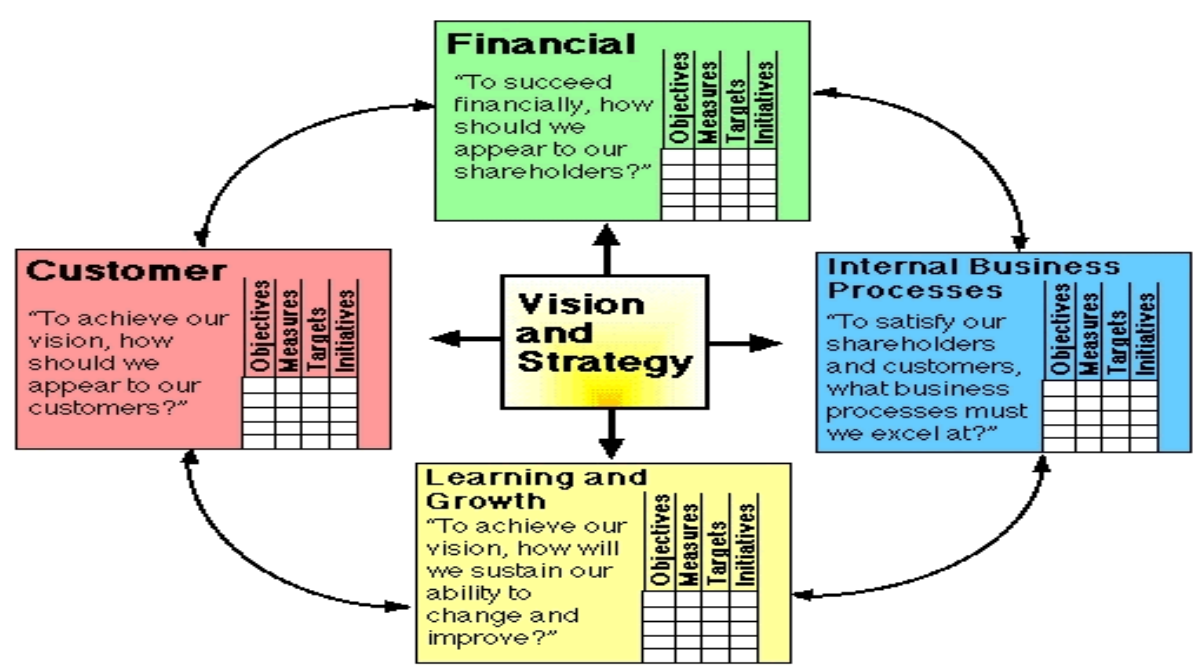

Gambar 2. Kerangka Kerja Balanced Scorecard [3] 


\section{Tolok Ukur Perancangan Service Scorecard (SSC)}

Dalam pembuatan "scorecard" ini diadaptasi berdasarkan situasi perusahaan. Beberapa fitur yang menonjol pada Service Scorecard antara lain: 1. Arsitektur Service Scorecard hanyalah titik mulai awal. Suatu perusahaan tidak akan membuat suatu pengukuran dan standarisasi yang sama dengan perusahaan lainnya; 2. Pengukuran yang ada hanya untuk menunjukkan aplikasi dari Service Scorecard tersebut; 3. Service Scorecard bisa meliputi 10 hingga 14 pengukuran pada level teratas; 4. Pengukuran umumnya berdasarkan organisasi tersebut dan telah dimengerti oleh stakeholder / pemegang kepentingan; 5. Service Scorecard akan menjadi patokan secara langsung atau tidak langsung untuk berkompetisi dan bersaing dengan perusahaan lain.

\section{Perancangan Service Scorecard}

Growth Perspective (Pertumbuhan): Perusahaan pelayanan jasa tumbuh dengan memperoleh pelanggan, memasuki pasar baru, menciptakan dan membawa jenis pelayanan yang baru dan menawarkan pelayanan yang lebih baik kepada pelanggan. Hal terpenting dan berkelanjutan harus dipertahankan untuk mengembangkan bisnis pelayanan jasa adalah menciptakan dan memberikan jenis-jenis pelayanan yang baru dan lebih baik dalam bentuk Innovasi keperluan konsumen.Inovasi strategi yang terdefinisi dengan jelas untuk diketahui setiap pelanggannya dan tetap merekrut, melatih, dan meningkatkan tenaga kerja yang memiliki fleksibilitas dan pemberdayaan khusus untuk membawa suatu ide dan inovasi kepada pasar.

\section{Leadership Perspective (Kepemimpinan):}

Elemen kepemimpinan didukung oleh elemen lain dalam scorecard untuk menciptakan suatu sinergi dan menghasilkan sinkronisasi diantara beberapa departemen. Peran Kepemimpinan sangat kritikal untuk menghasilkan dan menopang pertumbuhan yang menguntungkan.

Acceleration Perspective (Percepatan): hanya satu pengukuran sebagai indikator utama dari kinerja perusahaann yaitu acceleration (percepatan). Percepatan ini didefinisikan sebagai peningkatan rata-rata dari perusahaan tersebut.Untuk suatu organisasi yang ingin melakukan percepatan pada peningkatan organisasi, semua karyawan harus bersinergi.
Collaboration Perspective (Kolaborasi): didefinisikan sebagai hubungan kerjasama suatu kemitraan yang saling mengikat satu sama lain. Kerjasama dengan pemasok atau mitra kerja, atau kerjasama dengan mitra aliansi perusahaan tersebut. Pertimbangan suatu rantai pasok dibidang jasa hampir serupa dengan rantai pasokan suatu produk.Rantai pasokan suatu jasa termasuk konsumen terakhir, dengan kontribusi mereka terhadap pendapatan dari keseluruhan rantai perjalanan nilai suatu jasa. Berbagai kolaborasi dan kerjasama memberikan nilai terhadap konsumen akhir. Seringkali nilai ini tidak berwujud dan sulit mendefinisikannya dalam lingkungan pelayanan jasa.

InnovationPerspective (Inovasi): Service Scorecard membedakan antara keterlibatan karyawan dan inovasi pelayanan. Inovasi pelayanan meliputi inovasi kepemimpinan karyawan dalam keterlibatan karyawan dalm 3 level : strategi, taktis, dan operasi. Pada level strategi mendefinisikan diferensiasi keterlibatan karyawan dengan peranannya mengeksekusi strategi korporasi. Pada level taktis meliputi berbagai kebijakan, proses dan metrik untuk mengambil alih strategi keterlibatan karyawan menuju ke level berikutnya.

\section{Execution Perspective (Pelaksanaan): Pelaksanaan operasional meningkatkan performansi proses penilaian dan kecepatan respon. Tantangan operasional meningkatkan produktivitas, efisiensi dan mengurangi biaya dengan perbaikan proses bisnis. Perbaikan tersebut didorong oleh kebutuhan pelanggan dan pengendalian biaya.Tantangan operasional juga menyediakan standar metodologi dengan bahasa perusahaan yang umum. Elemen pelaksanaan dari Service Scorecard mempunyai 2 dimensi : Pelaksanaan strategi operasi yang diperlukan, dan peningkatan ketanggapan respon dari pelaksanaan tersebut. Pemakaian dari beberapa metodologi peningkatan operasional ini secara relatif merupakan hal yang baru pada sektor pelayanan kerja.}

Retention Perspective (Penilaian): Penilaian pelanggan adalah aspek penting dalam bisnis pelayanan jasa. Disebagian besar perusahaan jasa, peringkat penilaian pelanggan terhadap perusahaan tersebut berada diatas daripada posisi pemegang saham. Namun, manajemen pelanggan lebih sering diklasifikasikan sebagai sebuah seni. Metrik pelanggan lebih tidak di korelasikan dengan metrik 
performansi perusahaan dan juga tidak didefinisikan dengan jelas. Manajer lebih sering mengandalkan pada metrik keuangan perusahaan.

\section{Keterkaitan Antara Balance Scorecard dan Service Scorecard}

Dengan menurunkan Customer Perspective (Perspektifpelanggan) yang ada pada Balanced
Scorecard menjadi suatu Service Scorecard, maka dapat mengukur kinerja pelayanan yang sudah diterapkan oleh perusahaan. Hasil ini dapat digunakan untuk mengelola sistem pelayanan pelanggan agar menjadi lebih baik dalam rangka untuk meningkatkan kepuasan pelanggan dan dengan sendirinya akan meningkatkan jumlah pelanggan.

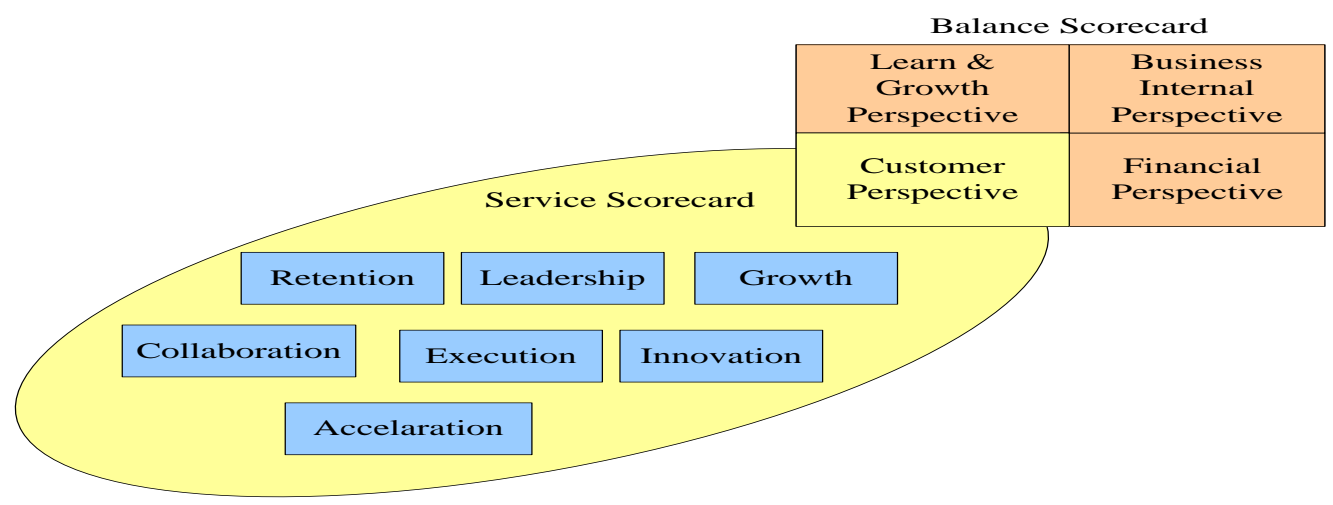

Gambar 3. Keterkaitan Antara Balance Scorecard dan Service Scorecard

\section{Kerangka Berpikir}

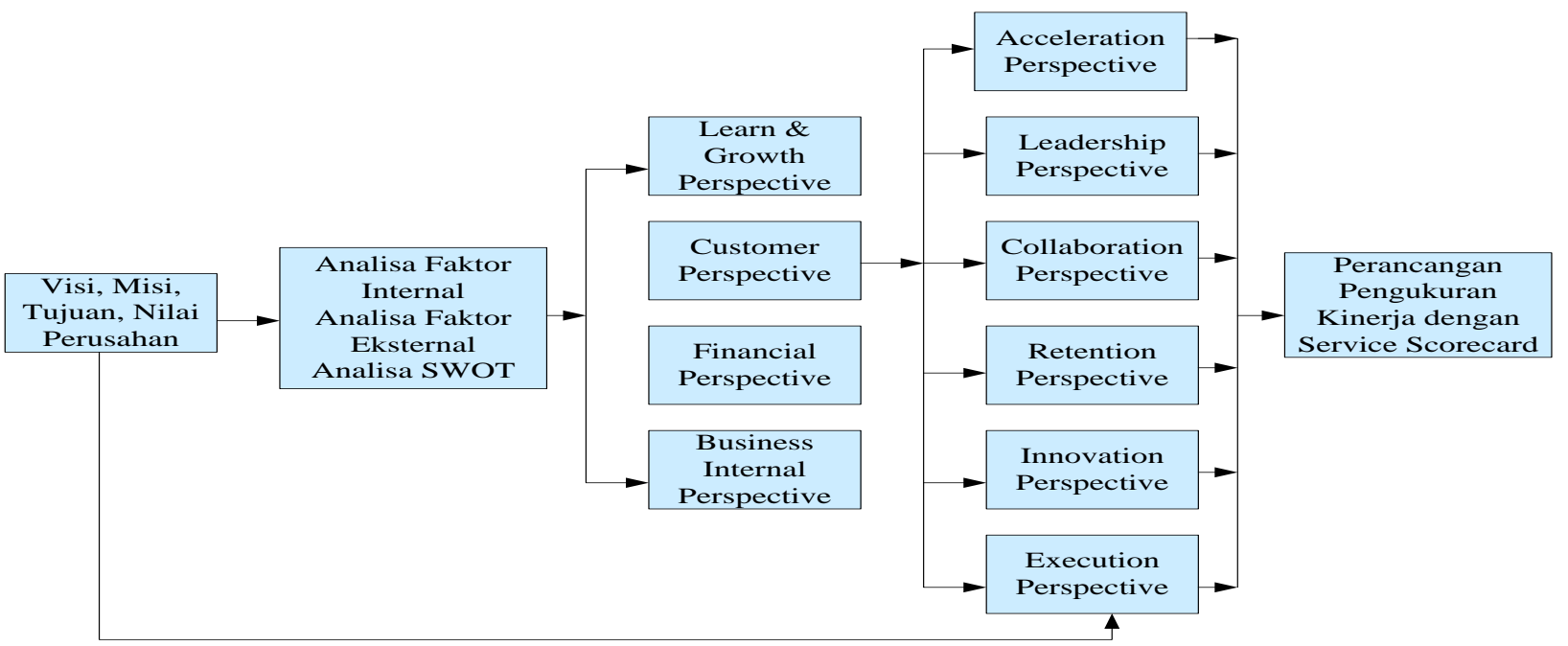

Gambar 4. Kerangka Berpikir

\section{Peta Strategi Service Scorecard}

Diagram yang menggambarkan bagaimana organisasi menciptakan nilai dengan menghubungkan tujuan strategis dalam hubungan sebab akibat yang jelas dengan setiap perspektif didalam service scorecard yaitu perspektif Growth, Leadership, Acceleration, Collaboration, Innovation, Execution dan Retention.

\section{HASIL DAN PEMBAHASAN}

Visi PT. PAS: Menjadi perusahaan penerbangan yang terkemuka di wilayah regional dan Misi PT. PAS: Menyediakan layanan dengan tingkat keamanan yang tinggi kepada pelanggan. Pengolahan data berdasarkan hasil kuisioner kepada Direksi PAS sebagai expert judgement 
terhadap faktor-faktor internal maupun faktor eksternal. Setelah itu dilakukan perhitungan skor hasil bobot dan rating matriks IFE dan matriks EFE terlihat pada Tabel 1 dan Tabel 2. Nilai skor matriks IFE dan EFE yang didapat adalah sebesar 4.258 dan 4,0397 .

\section{Matching Stage}

Perhitungan skor matriks IFE dan EFE dilanjutkan dengan menggabungkan keduanya pada matriks internal-eksternal. Nilai skor matriks IFE dan EFE yang didapat adalah sebesar 4.258 dan 4,0397. Pada Gambar 5 Matriks Internal-Eksternal menujukkan perusahaan berada pada sel I, yakni tahap pertumbuhan. Tahap ini digambarkan berada pada posisi bertumbuh "Grow" dan membangun "Build". Ada 3 strategi utama yang sesuai: strategi bauran dan pertumbuhan pendapatan pada aspek finansial, strategi Intensif pada aspek pemasaran dan strategi terintegrasi pada aspek bisnis proses.

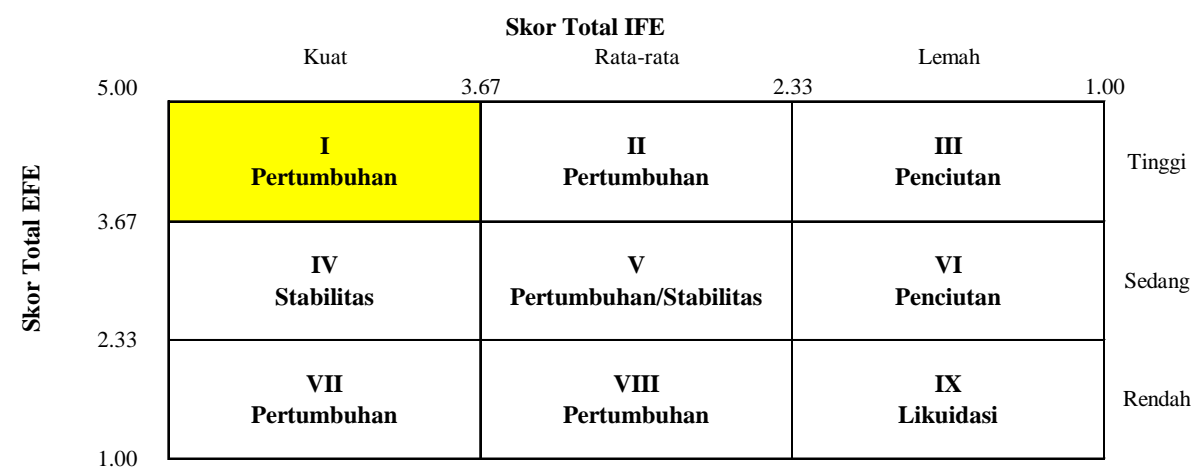

Gambar 5. Matriks IFE dan EFE

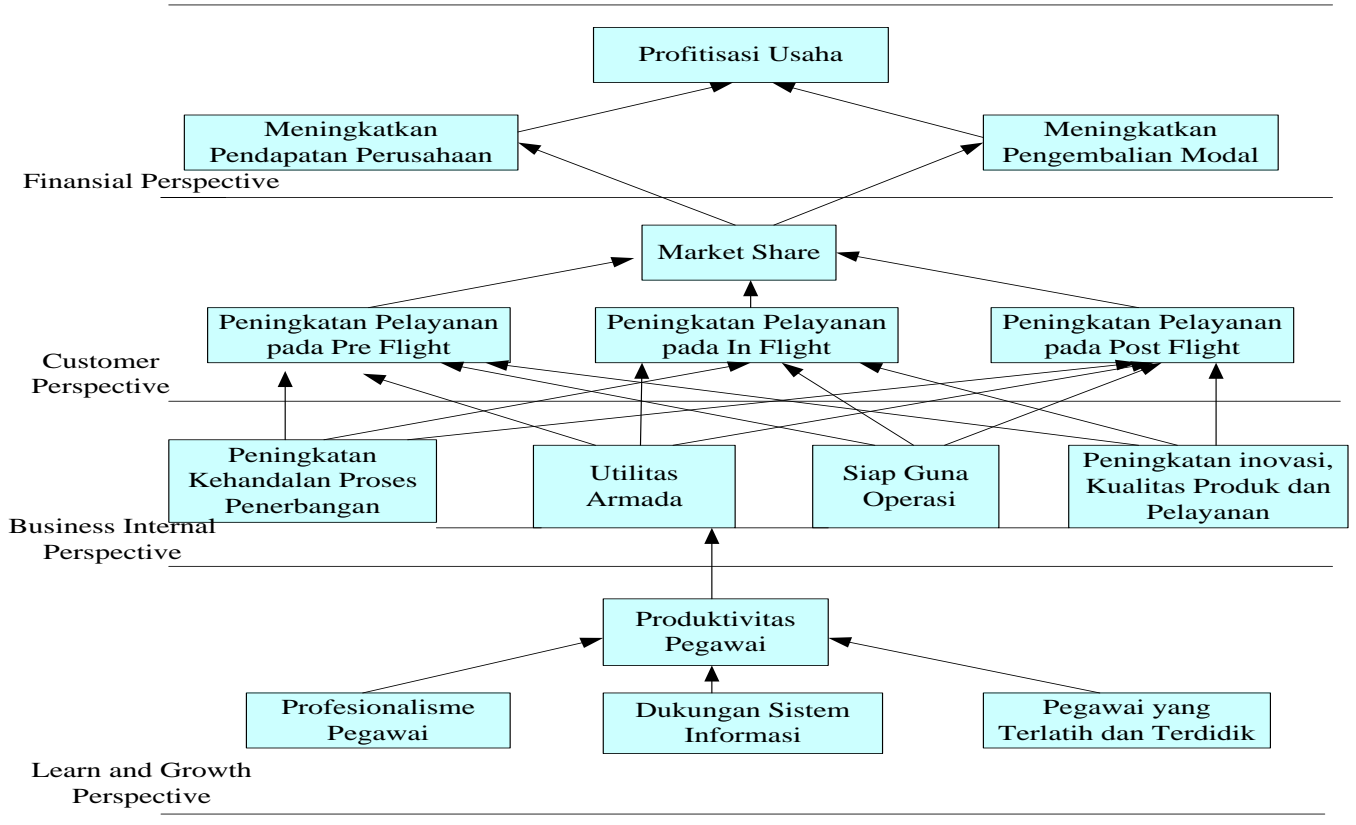

Gambar 6. Peta Strategi Balance Scorecard

\section{Peta Strategi Balanced Scorecard}

Peta Strategi dengan menggunakan perspektif Balanced Scorecard, merupakan hasil yang diturunkan dari penelitian terdahulu yang akan diambil sebagai landasan dasar pada pembuatan peta strategi dengan menggunakan perspektif pada Service Scorecard (Gambar 6).
Inti dari perspektif pelanggan pada Balanced Scorecard adalah bagaimana meningkatkan pelayanan sehingga dapat meningkatkan kepuasan pelanggan. Pelayanan (service) yang diberikan kepada pelanggan khususnya perusahaan penerbangan PT. PAS meliputi: a)Pre Flight (pelayanan sebelum penerbangan), b)In Flight 
(pelayanan saat penerbangan), c)Post Flight (pelayanan setelah penerbangan). Pelayanan yang diberikan perusahaan penerbangan PT. PAS terlihat pada Gambar 7.

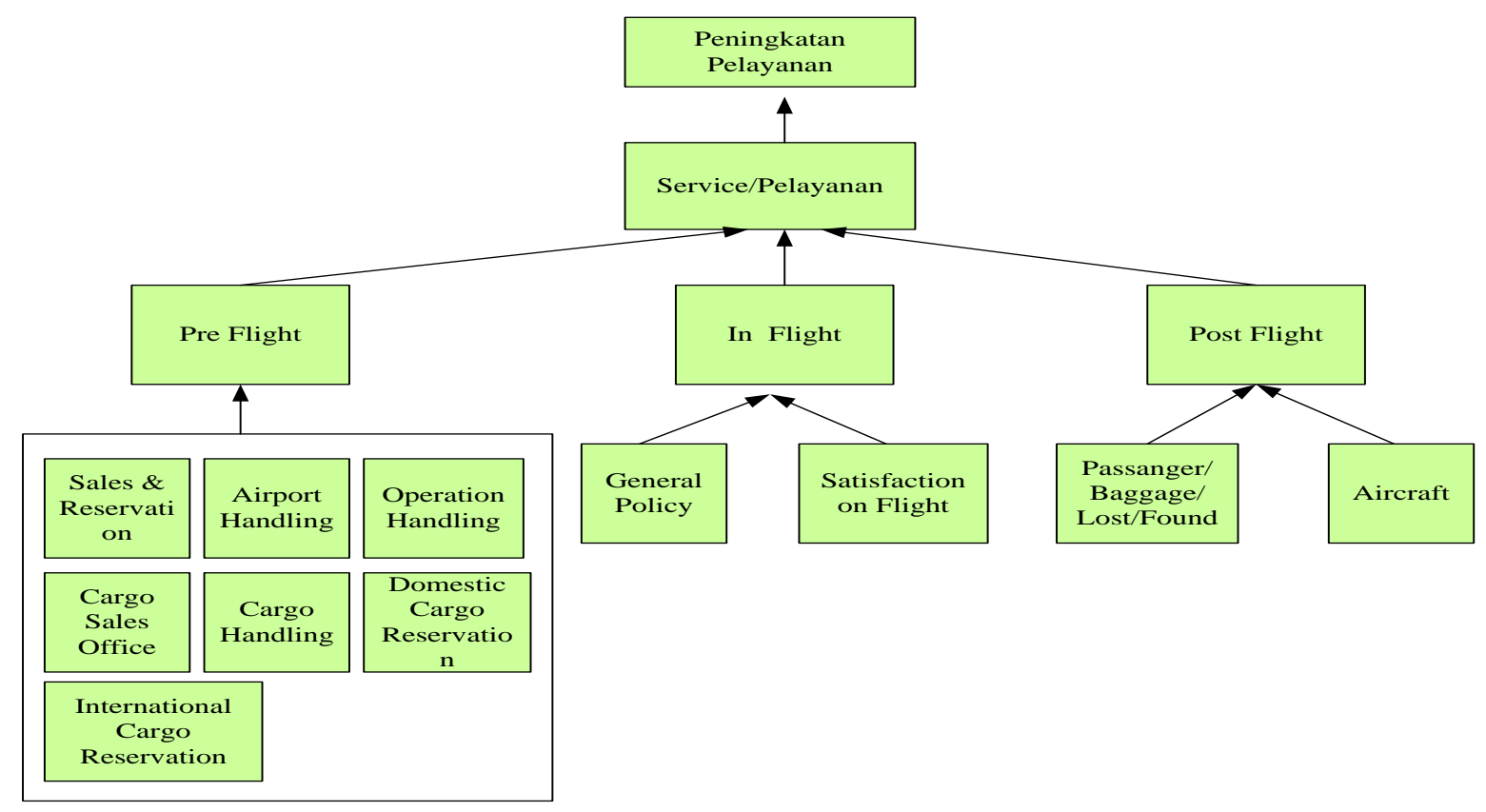

Gambar 7. Peningkatan Pelayanan Kinerja PT. X

\section{Perancangan Service Scorecard}

Berdasarkan hasil benchmarking dengan pihak perusahan, diperoleh penjelasan mengenai stategi yang dapat diterapkan pada perspektif Service Scorecard.

\section{Growth Perspective}

Ketika penerapan strategi pada korporasi berjalan sukses, pemimpin harus fokus juga terhadap pertumbuhan keuntungan, tidak hanya terbatas pada besaran keuntungan itu sendiri. Growth dapat diukur dengan penambahan atau perluasan bisnis yang berbanding lurus dengan pertambahan pelanggan pula. Pada perspektif ini, strategi yang bisa dikembangkan yaitu, peningkatan pangsa pasar dan penambahan jenis bisnis.

\section{Leadership Perspective}

Kepemimpinan pada organisasi merupakan hal yang sangat krusial dalam membuat suatu visi organisasi, pengembangan strategi, pelaksanaan rencana strategi, dan meraih kesuksesan. Umumnya, dalam hampir semua organisasi, kepemimpinan diukur secara menyeluruh pada performansi finansial yang terlihat pada nilai saham dan total aset. Kebijakan yang telah dilaksanakan perusahaan diantaranya dengan peningkatan pendapatan pada pegawai, Return of Asset, Return of Investment, pemberian penghargaan bisa menjadi suatu kebijakan dalam suatu kepemimpinan yang baik dan memotivasi untuk mencapai targetperusahaan.

\section{Acceleration Perspective}

Tujuan dari pembuatan elemen Acceleration adalah untuk mengejar kekurangan yang ada di perusahaan agar memiliki performansi bisnis yang lebih baik. Perusahaan penerbangan berupaya memenuhi kebutuhan pelanggan yang berorientasi pada harga yang murah. Harapan pelanggan ini tidak seiring dengan upaya untuk mewujudkan pertumbuhan keuntungan secara berkelanjutan. Untuk memenuhi permintaan pelanggan, strategi bisnisnya yaitu dengan menyediakan atau menambah pelayanan sehingga menjadi lebih baik dan lebih berkualitas, daripada harus mengurangi kualitas.

\section{Collaboration Perspective}

Keberhasilan suatu organisasi sangat bergantung pada performansi suppliernya, penyedia layanannya, atau jaringan kerjasamanya. Collaboration adalah sebuah aksi untuk membuat suatu kemitraan yang memiliki nilai tambah. Secara global, collaboration membuat suatu dimensi yang kritikal pada sebuah bisnis yang mencari sukses secara berkelanjutan. Collaboration dapat berhubungan dengan pemasok, pelanggan, konsumen, pegawai, atausiapapun yang dapat berkontribusi untuk 
mendapatkan suatu solusi dalam hal penyediaan pelayanan kepada pelanggan. Pada perspektif ini, strategi yang dapat dibuat yaitu antara lain : 1.Memperbaiki tingkat keamanan, yaitu keamanan barang-barang yang dibawa oleh para konsumen dengan cara bekerjasama dengan pihak bandara; 2.Merevisi level harga jasa layanan charter sehingga dapat bersaing, dengan cara memintaharga yang lebih murah mulai dari segi suku cadang ataupun biaya operasional dari pemasok / supplier.

\section{Innovation Perspective}

Pengembangan Innovation pada adalah salah satu elemen penting untuk menjaga dan mempertahankan kualitas pelayanan jasa charter penerbangan. Inovasi pelayanan tidak hanya dalam hal membuat suatu desain inovasi atau produk, tetapi lebih menitikberatkan kepada berfikir secara inovatif pada level aktifitas pada saat yang samamemberikan pengalaman yang diinginkan pelanggan.Tipe dari inovasi yang sudah dikembangkan oleh perusahaan mencakup model bisnis, pasar, operasional, proses, pengalaman dan inovasi sesuai permintaan. Strategi yang dapat dikembangkan pada inovasi ini, antara lain:a)Pemberian fasilitas berupa "welcome food and drink", diruang tunggu bandara, b)Peningkatan level kepuasan dengan pemberian fasilitas antar jemput rombongan, dimanaakan membuat pelanggan merasa lebih praktis, c)Peningkatan level kenyamanan dengan meningkatkan tingkat keramahan karyawan terhadap calon pelanggan, d)Inovasi terhadap peningkatan sistem pembelian tiket / booking charter pesawat, bisa dikembangkan dengan pemesanan melalui email ataupun sistem informasi yang lebih canggih, dan e)Upaya untuk meningkatkan relativitas pangsa pasar sesuai dengan fasilitas yang diberikan.

\section{Execution Perspective}

Execution secara sederhana memiliki arti yaitu keunggulan dalam penyampaian pelayanan jasa secara langsung.Dalam menjalankan eksekusi kebijakannya, perusahaan sudah mengatur dan memprosesnya secara matang. Keunggulan dapat didefinisikan dalam pencapaian target pelayananjasa. Pada perspektif ini, strategi yang dapat dikembangkan antara lain : 1. Akurasi jumlah jam penerbangan sesuai dengan perencanaan; 2. Pengurangan seringnya delay waktu penerbangan (on-time project delivery).

\section{Retention Perspective}

Pelanggan akan memiliki memory / ingatan yang baik dari pelayanan yang diberikan perusahaan penerbangan. Untuk mempertahankan loyalitas pelanggan sepertinya lebih mudah daripada memperoleh lebih banyak pelanggan baru lagi.Pada perspektif ini, strategi yang dapat dikembangkan, antara lain :a)Pemberian pelayanan jasa secara ramah dan sopan, b)Peningkatan level kenyamanan yang baik didalam penerbangan, c)Penurunan peluang hilangnya calon pelanggan karena suatu keterlambatan, baikketerlambatan respon pelayanan, ataupun keterlambatan waktu standar penerbangan.

\section{Keterkaitan Antara Balanced Scorecard dan Service Scorecard}

Dari peningkatan kinerja pelayanan PT. X pada gambar 6 di atas, kemudian dihubungkan dengan 7 perspektif dari Service Scorecard dapat terlihat pada gambar 8 .

\section{Peta Strategi Service Scorecard \& Lead $n$ Lag Indicator}

Berdasarkan hasil di atas maka dirancang peta strategi dari Service Scorecard yang bertujuan untuk mendapatkan sasaran dan tujuan yang strategis untuk dapat melihat keterkaitan antara setiap elemen yang terdapat pada setiap tingkatan perspektif Service Scorecard. Peta strategi Service Scorecard dirancang dan dibuat berdasarkan datadata yang telah disebutkan dalam analisa sebelumnya pada alignment perancangan Balance Scorecard dihubungkan terhadap Service Scorecard, terlihat pada Gambar 9. 


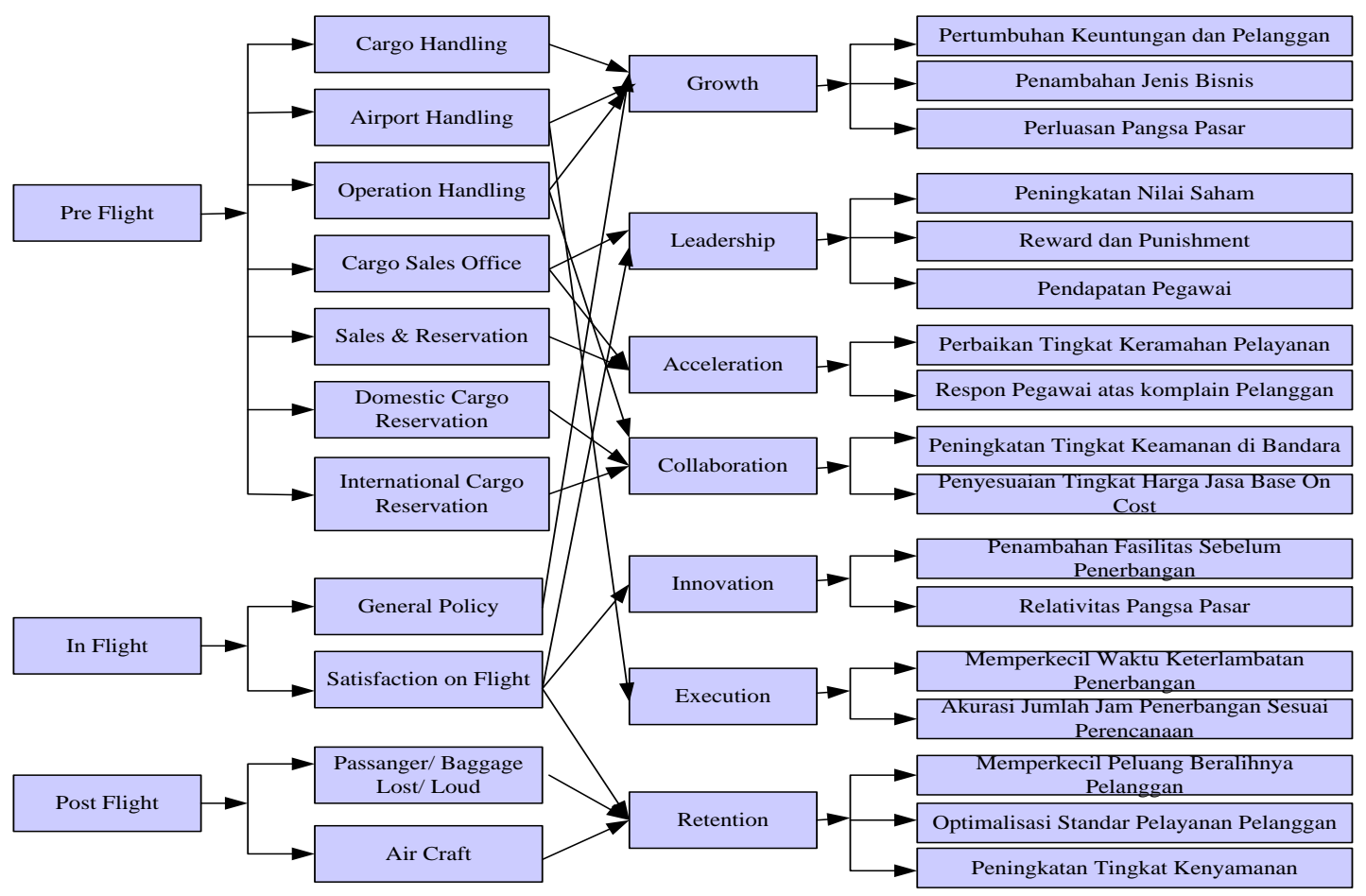

Gambar 8. Hubungan Customer Perspective dengan Service Scorecard

\section{KESIMPULAN}

Berdasarkan perancangan kinerja pelayanan jasa pada perusahaan penerbangan PT.PAS, model Service Scorecard, mampu mengetahui posisi perusahaan di mata pelanggan. Metode ini juga berhasil merumuskan visi dan misi ke dalam suatu tujuan strategis. Penelitian ini harus dilanjutkan dengan melakukan pengukuran kinerja pada perusahaan penerbangan PT. PAS dengan menentukan tolok ukur, target dan inisiatif strategis sehingga dapat ditentukan kinerja dari ke7 perspektif pada model Service Scorecard, selanjutnya dilakukan pembobotan dengan menggunakan metode Pairwise Comparison. Dengan demikian, perusahan dapat mengevaluasi kinerja pelayanan jasa yang telah dilakukannya selama ini.

\section{DAFTAR PUSTAKA}

[1] F. Kaitosh, "Why the Consumer Price index is Controversial". [Online]. Available: www.Alicekomputer.wordpress.com, "Tentang Pengukuran Kinerja dengan Balanced Scorecard" [Accessed 4 November 2014].
[2] R. K. Tyagi and P. Gupta, "A Complete and Balanced Service Scorecard Creating Value Through Sustaianed Perfomance Improvement", Library of Congress Cataloging Publication Data, Pearson Education Singapore, 2008.

[3] R. Kaplan and D. Norton, The Balanced Scorecard: Translating Strategy into Action, edisi satu, United States : Harvard Business School Press, 1996.

[4] A. A. Anwar Prabu Mangkunegara, Manajemen Sumber Daya Manusia Perusahaan, cetakan pertama, Bandung: PT. Remaja Rosdakarya, 2000.

[5] F. R. David, Strategic Management (Manajemen Strategis), Jakarta: PT. Indeks Kelompok Gramedia, 2004.

[6] T. H. Handoko, Manajemen Personalia dan Sumberdaya Manusia, Yogyakarta: BPFE Yogyakarta, 1994.

[7] M. A. Huselid, B. E. Becker, and R W. Beatty, The Workforce Scorecard : Managing Human Capital to Execute Strategy, United States: Harvard Bussiness School Publishing Corporation, 2005.

[8] Mulyadi, Balanced Scorecard: Alat Manajemen Kontemporer untuk Pelipatganda Kinerja Keuangan Perusahaan, Edisi 2, Jakarta: Salemba Empat, 2001.

[9] Mulyadi, "Alternatif Pemacuan Kinerja Personel dengan Pengelolaan Kinerja Terpadu Berbasis Balanced Scorecard" Jurnal Ekonomi dan Bisnis Indonesia, Vol.20, No.3, 2005.

[10]H. Pasolong, Teori Administrasi Publik, Bandung: Alfabeta, 2007. 
Tabel 1. Perhitungan Skor Hasil Bobot dan Rating Matriks IFE

\begin{tabular}{|c|c|c|c|}
\hline $\begin{array}{l}\text { Key Internal Factors } \\
\text { Kekuatan (Strength) }\end{array}$ & Bobot & Rating & Skor \\
\hline $\begin{array}{l}\text { Memiliki nama yang baik dikarenakan nama perusahaan masih } \\
\text { menjadi perusahaan charter terbaik di Indonesia }\end{array}$ & 0,066 & 4,75 & 0,314 \\
\hline Memiliki awak pesawat yang berpengalaman & 0,059 & 4,75 & 0,280 \\
\hline Memiliki kehandalan pesawat yang tinggi (High Dispatch Reliability) & 0,066 & 4 & 0,264 \\
\hline Memiliki tingkat keselamatan yang tinggi (High Safety Level) & 0,062 & 4,5 & 0,279 \\
\hline Memiliki sarana pemeliharaan pesawat yang mandiri & 0,055 & 4,5 & 0,248 \\
\hline Menerapkan sistem informasi yang terintegrasi & 0,059 & 4,75 & 0,280 \\
\hline Mengaplikasikan standar manajemen mutu & 0,062 & 4,5 & 0,279 \\
\hline Memiliki networking yang baik di industri charter & 0,062 & 4 & 0,248 \\
\hline \multicolumn{4}{|l|}{ Kelemahan (Weakness) } \\
\hline Tingginyaa permintaan & 0,055 & 3,5 & 0,193 \\
\hline Pengambilan keputusan yang terlalu birokratif & 0,059 & 3,75 & 0,221 \\
\hline Terbatasnya dana untuk pembelanjaan modal & 0,055 & 4 & 0,22 \\
\hline $\begin{array}{l}\text { Manajemen pemasaran, termasuk pengelolaan } 4 \mathrm{P} \text { dan CRM belum } \\
\text { optimal }\end{array}$ & 0,059 & 4 & 0,221 \\
\hline Manajemen HR yang belum baik & 0,055 & 3,75 & 0,206 \\
\hline Sistem Reward and Punishment yang tidak jelas & 0,052 & 4 & 0,258 \\
\hline Tingginya biaya overhead perusahaan & 0,059 & 4 & 0,236 \\
\hline \multicolumn{3}{|l|}{ oo } & 4,258 \\
\hline
\end{tabular}

Tabel 2. Perhitungan Skor Hasil Bobot dan Rating Matriks EFE

\begin{tabular}{|c|c|c|c|}
\hline $\begin{array}{l}\text { Key Eksternal Factors } \\
\text { Peluang (Opportunities) }\end{array}$ & Bobot & Rating & Skor \\
\hline Pertambahan rute-rute jalur penerbangan & 0,122 & 4 & 0,488 \\
\hline $\begin{array}{l}\text { Peningkatan jumlah perusahaan yang membutuhkan jasa pelayanan } \\
\text { charter }\end{array}$ & 0,115 & 3,75 & 0,431 \\
\hline Peningkatan pertumbuhan bisnis cargo di Indonesia & 0,115 & 4 & 0,46 \\
\hline Peningkatan kebutuhan angkutan udara secara kolektif & 0,130 & 4,25 & 0,5525 \\
\hline \multicolumn{4}{|l|}{ Ancaman (Threats) } \\
\hline Tumbuhnya perusahaan sejenis dalam bisnis charter penerbangan & 0,130 & 3,75 & 0,4875 \\
\hline $\begin{array}{l}\text { Persaiangan pada efisiensi operasional penerbangan dan maitenance } \\
\text { suku cadang }\end{array}$ & 0,122 & 4,25 & 0,5185 \\
\hline Persaingan harga dari kompetitor dengan kualitas yang setara & 0,130 & 4 & 0,52 \\
\hline $\begin{array}{c}\text { Tingginya tuntutan pelanggan terhadap kualitas pelayanan } \\
\text { Total }\end{array}$ & 0,137 & 4,25 & $\begin{array}{l}0,5822 \\
\mathbf{4 . 0 3 9 7}\end{array}$ \\
\hline
\end{tabular}




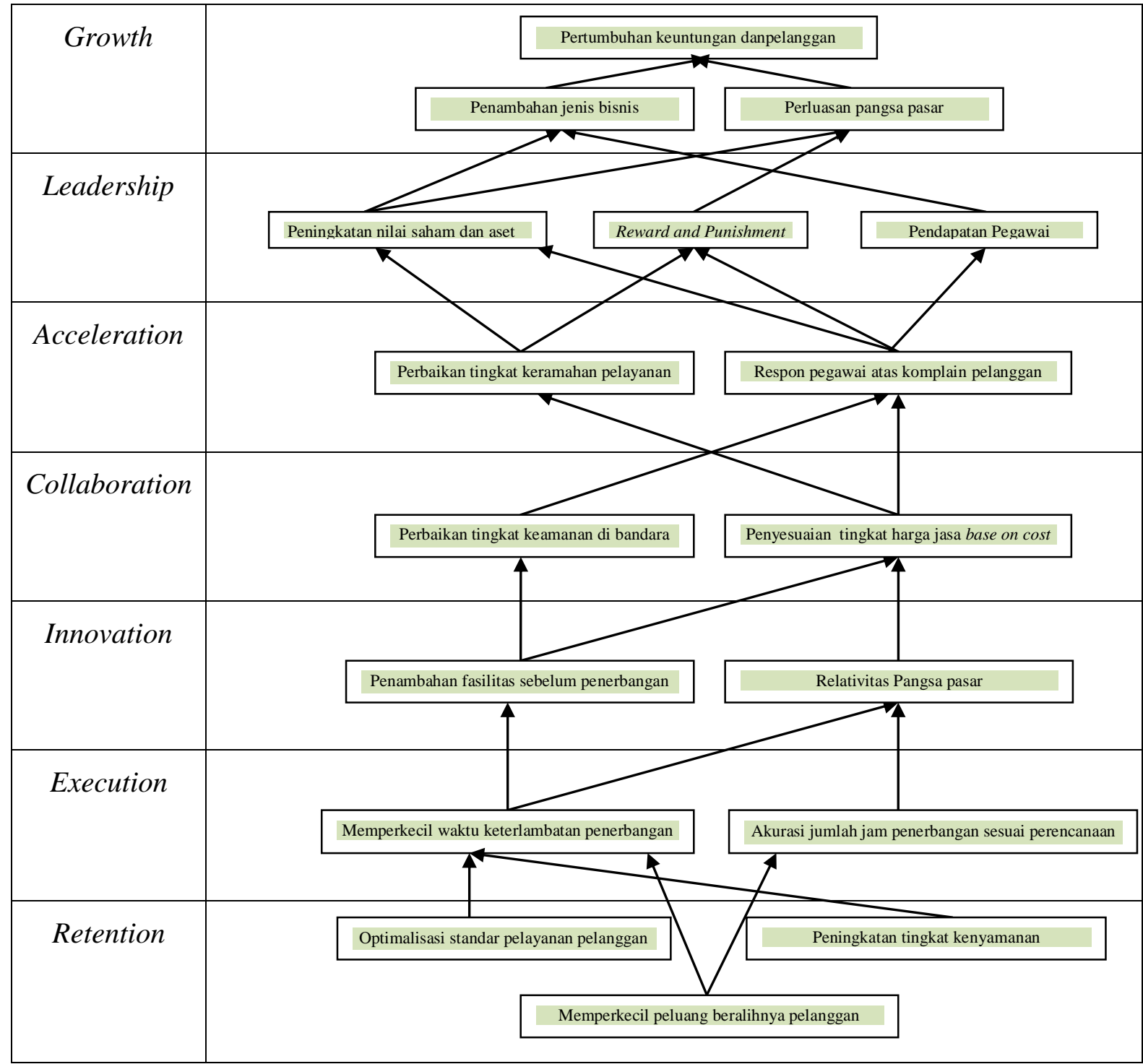

Gambar 9. Peta Strategi Service Scorecard 


\begin{tabular}{|c|c|c|}
\hline \multirow{2}{*}{ Tujuan Strategis Perusahaan } & \multicolumn{2}{|c|}{ Ukuran Strategis } \\
\hline & Lag Indicator & Lead Indicator \\
\hline \multirow{4}{*}{$\begin{array}{c}\text { Growth Perspective } \\
\text { Pertumbuhan Profit dan Customer } \\
\text { Penambahan jenis bisnis } \\
\text { Perluasan pangsa pasar }\end{array}$} & & \\
\hline & Level earn profit perusahaan & Peningkatan jumlah laba \\
\hline & Tingkat produktivitas & Kerjasama internal yang baik \\
\hline & Level cakupan pasar & $\begin{array}{l}\text { Manajemen Marketing yang } \\
\text { terstruktur rapi }\end{array}$ \\
\hline \multirow{3}{*}{$\begin{array}{c}\text { Leadership Perspective } \\
\text { Peningkatan nilai saham dan aset } \\
\text { Reward and Punishment } \\
\text { Pendapatan Pegawai }\end{array}$} & & \\
\hline & Level ekonomi perusahaan & $\begin{array}{l}\text { Manajemen Finansial yang } \\
\text { terstruktur rapi }\end{array}$ \\
\hline & Jumlah Reward \& Punishment & Tingkat disiplin pegawai \\
\hline \multirow{3}{*}{$\begin{array}{c}\text { Acceleration Perspective } \\
\text { Perbaikan tingkat keramahan pelayanan } \\
\text { Respon pegawai atas komplain } \\
\text { pelanggan }\end{array}$} & Tingkat Pendapatan pegawai & Pertumbuhan Pendapatan \\
\hline & Level keterampilan & Kehandalan dalam bekerja \\
\hline & Tingkat profesionalisme & \multirow{2}{*}{$\begin{array}{l}\text { Pelatihan pegawai untuk cepat } \\
\text { tanggap }\end{array}$} \\
\hline \multirow{4}{*}{$\begin{array}{c}\text { Collaboration Perspective } \\
\text { Perbaikan tingkat keamanan di bandara } \\
\text { Penyesuaian tingkat harga jasa base on } \\
\text { cost }\end{array}$} & \multirow[b]{3}{*}{ Level keamanan / Safety Level } & \\
\hline & & \multirow[b]{2}{*}{ Jaminan keamanan di bandara } \\
\hline & & \\
\hline & Level harga / Pricing Level & Biaya yang dikeluarkan \\
\hline \multirow{3}{*}{$\begin{array}{c}\text { Innovation Perspective } \\
\text { Penambahan fasilitas sebelum } \\
\text { penerbangan } \\
\text { Relativitas Pangsa Pasar }\end{array}$} & & \multirow[b]{2}{*}{$\begin{array}{l}\text { Jumlah fasilitas-fasilitas } \\
\text { pendukung }\end{array}$} \\
\hline & Level inisiatif & \\
\hline & Level Jenis pasar & Penambahan relativitas pasar \\
\hline Execution Perspective & & \\
\hline $\begin{array}{c}\text { Memperkecil waktu keterlambatan } \\
\text { penerbangan }\end{array}$ & Tingkat Kepuasan Pelanggan & Ketepatan waktu penerbangan \\
\hline $\begin{array}{c}\text { Akurasi jumlah jam penerbangan sesuai } \\
\text { rencana }\end{array}$ & Tingkat Efektifitas pelayanan & Ketepatan siklus operasional \\
\hline $\begin{array}{c}\text { Retention Perspective } \\
\text { Memperkecil peluang beralihnya }\end{array}$ & & \\
\hline $\begin{array}{c}\text { pelanggan } \\
\text { Optimalisasi standar pelayanan }\end{array}$ & Customer losses of accounts & Loyalitas pelanggan \\
\hline $\begin{array}{l}\text { pelanggan } \\
\text { pela }\end{array}$ & Tingkat kesesuaian SOP & Kedisiplinan mendirikan SOP \\
\hline & Level Kenyamanan & Pengalaman penerbangan \\
\hline
\end{tabular}

Gambar 10. Lead and Lag Indicator Service Scorecard 